\title{
Caleb, Son of Jephunneh - As an Example of Fidelity to God. An Exegetical Study of Sir 46:7-10
}

\author{
JUDYTA JOLANTA PUDEŁKO \\ Catholic Academy in Warsaw \\ judyta.pd@gmail.com \\ ORCID: 0000-0001-5392-4109
}

\begin{abstract}
Caleb is a secondary character in several episodes of the Exodus as well as the conquest of the Promised Land (Num 13-14; Josh 14:6-14). Praise of the Ancestors (Sir 44-49) contains a presentation of the biblical history of ancient Israel as the history of the covenant and a place of God's intervention. According to his own criteria, Sirach presents the most relevant and positive characters in this history. In Sirach's description (46:7-10), Caleb is a faithful scout, who, together with Joshua, faced with the rebellion of the Israelites, bears witness to an exemplary trust in God and encourages the Israelites to follow his lead. His courage and faithfulness are rewarded by receiving an inheritance of some ground in the Promised Land, which then becomes the property of his offspring. In the brief account of Sirach, Caleb is a timeless example of a faithful man - one who lives according to the word of God and encourages others to take up this challenge.
\end{abstract}

KEYwORDs: Praise of the Ancestors; Sir 44-49; Sir 46:7-10; Caleb (son of Iepphonne)

In the Holy Bible, Caleb, son of Jephunneh (cf. Num 13:6) is a secondary character associated with isolated episodes of the exodus period, the settlement of Canaan, and does not belong to the figures often mentioned in biblical books. ${ }^{1}$ Yet it was he who was called "my servant" by God Himself and was recognized as the first one worthy of entering the Promised Land (cf. Num 14:24), receiving the strategically important territories of Judah with Hebron (cf. Josh 14:13). ${ }^{2}$ The name Caleb is

1 We do not have many studies on Caleb, apart from commentaries on the pericopes in which he appears: W. Beltz, Die Kaleb-Traditionen im Alten Testament (BWANT 18; Stuttgart: Kohlhammer 1974); M.J. Fretz - R.I. Panitz, "Caleb (Person)," The Anchor Yale Bible Dictionary (ed. DN Freedman) (New York: Doubleday 1992) I, 808-810. In both Jewish and Christian traditions, the figure of Caleb has received many non-biblical interpretations. See on this subject: A. Domański, "The Figure of Caleb in Selected Jewish Legends and in the Teaching of the Church Fathers," StLov 7 (2005) 95-107.

2 Nabal, Abigail's husband, was a Calebite, (cf. 1 Sam 25:3), who later became David's wife. David, therefore, by marrying the widow of Nabal, took over the inheritance of Caleb and became lord in Hebron, where he ruled over the tribe of Judah (cf. 2 Sam 2:11). Cf. Fretz - Panitz, "Caleb (Person)," 809. See on this subject: J.D. Levenson - B. Halpern, "The Political Import of David's Marriages," JBL 99 (1980) 507-518. 
derived from the Hebrew term כֶלֶ which means "dog." 3 In Semitic culture, calling a person a dog often had a derogatory character, since dogs, being scavengers, were considered unclean animals (cf. $1 \mathrm{Kgs} \mathrm{14:11).}{ }^{4}$ The term was used to speak of someone in a contemptuous way (cf. 1 Sam 24:15; 2 Sam 3:8; Isa 56:10-11). The term "dog" was also used to describe a male prostitute (cf. Deut 23:18). On the other hand, in Egypt, one could encounter deification of dogs, which were also used for hunting there. ${ }^{5}$ In the Akkadian language, the term "dog" appeared as part of a longer, theophoric name, e.g., "kalbi - Sin/Marduk" ("obedient servant of Marduk"). In a positive sense, comparing someone to a dog meant a very loyal person, a faithful servant (cf. $2 \mathrm{Kgs} \mathrm{8:13).}{ }^{6}$ However, Caleb son of Jephunneh was not of Israelite descent. He was a Kenizzite (cf. Num 32:12; Josh 14:6), incorporated into the tribe of Judah (cf. Num 13.3; 1 Sam 27:10). ${ }^{7}$

In Praise of the Fathers (Sir 44-49), Sirach, the sage of Jerusalem, presents the heroes of Israel's history deserving of remembrance and recognition. He

3 This term appears 32 times in Biblia Hebraica to denote animals, human names, and in a figurative sense. Two or three persons who bear a name derived from this term can be identified in the Holy Bible: Caleb son of Jephunneh (1 Chr 4:15), Caleb son of Hezron (1 Chr 2:18). A third name appears: Chelubai, who is mentioned as the son of Hezron (1 Chr 2:9) and may therefore be another variant of the same name. Cf. Fretz - Panitz, "Caleb (Person)," 808; G.J. Botterweck, "כלב," Theological Dictionary of the Old Testament (eds. G.J. Botterweck - H. Ringgren) (Grand Rapids, MI - Cambridge, U.K.: Eerdmans 1995) V, 147; D.W. Thomas, "Kelebh «dog»: Its Origin and Some Usages of It in the Old Testament," VT 10/4 (1960) 410.

4 "It is mentioned that this is in the nature of dog to return to its excrements (Prov 26:11;2 Pet 2:22), eats waste and corpses, licks the blood of victims and wounds of the sick (1 Kgs 21:19; 22:38; 2 Kgs 9) 10:36; Ps 68:24; Jer 15:3; Luke 16:21). It is also mentioned that it is used in pagan cults (Deut 23:19; Isa 66:3; Rev 22:15). For this reason, it was also treated as an unclean animal, similar to a hyena (Sir 13:18), and thus unclean meat could be fed to it (Exod 22:30). This negative attitude was probably also influenced by the fact that in biblical times in Palestine herds of stray and semi-

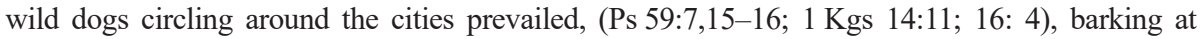
people (Exod 11:7; Jdt 11:19) and inspiring horror with their behavior (Ps 22:17,21; Prov 26:17)." J. Lemański, "Negatywny obraz psa w Biblii: przyczyny i konsekwencje," CTO 1 (2011) 60.

5 Cf. Botterweck, "כלב," 148; Lemański, "Negatywny obraz psa w Biblii: przyczyny i konsekwencje," 56.

6 Cf. J. Milgrom, Numbers. The Traditional Hebrew Text with the New JPS Translation (Philadelphia, PA - New York: Jewish Publication Society 1990) 101, 391.

7 The Kenizzites are descended from Kenaz, a descendant of Esau (cf. Gen 36:10-11,42; 1 Chr 1:36.52-53). Cf. Beltz, Die Kaleb-Traditionen im Alten Testament, 66; Milgrom, Numbers, 391. "It ts understandable that Caleb's ethnicity and belonging to the tribe of Judah are a subject of discussion. The views of the exegetes on this subject can be summarized in three points: The Kenizzites were an ethnic group incorporated into the Edomites, then they were incorporated into the tribe of Judah (assuming that Caleb was born in Egypt); Jephunneh the Kenizzite married a wife of the Caleb's house (1 Chr 2:8-20), and Caleb was their son; Jephunneh had a second wife, and Othniel and Seraiah were born of her (1 Chr 4:13); The Kenizzites were always part of the Judah tribe and did not stay in Egypt; Probably the Edomite clans, including the Kenaz clan, first inhabited the mountainous areas of Judea and the Negeb (1 Sam 30:14), later they were incorporated into the tribe of Judah (Num 13:6)." S. Wypych, Księga Jozuego. Wstęp, przektad z oryginatu, komentarz (NKB.ST 6; Częstochowa: Edycja Świętego Pawła 2015) 345. 
draws on the books and stories already available but makes his own assessment of the characters according to the criteria he has adopted. Not all famous heroes are included in this praise. ${ }^{8}$ Surprisingly, the secondary figure of Caleb is listed therein, whom Sirach praises along with Joshua (cf. 46:7-10). The four verses concerning Caleb, present in the Praise of the Fathers constitute concise, synthetic material, selected by Sirach from the sources available to him. This article, through an analysis of the intertextual references present in the text of the Book of Sirach, will attempt to answer the question: why, from the perspective of the sage from the second century $\mathrm{BC}$, was Caleb, an episodic hero of ancient history, a figure sufficiently significant to be commemorated for posterity? The first part of this article will present references to the figure of Caleb in the Old Testament outside the Book of Sirach in order to identify the verses and themes used by the sage of Jerusalem in praising Caleb. The pericope of Sir 46:7-10 will then be analysed in the context of the Praise of the Fathers (Sir 44-49), taking into account the textual complexity of the book (Greek and Hebrew versions). The figure of Caleb in the Book of Sirach has rarely been the subject of studies, and they usually treat about the praise of Joshua, addressing Caleb collaterally. ${ }^{9}$ This article, however, focuses on the character of Caleb, although he is clearly linked to the person of Joshua in the Book of Sirach.

\section{Caleb in the Old Testament}

Caleb appears in the biblical story both in the context of wandering across the desert and conquering the Promised Land. The first mentions, described in Num 13-14, refer to Moses sending out scouts to explore Canaan in order to assess the value of the land and the possibility of its conquest. Moses appointed one man from each tribe of Israel, and Caleb, son of Jephunneh, was chosen as the representative of the tribe of Judah (cf. Num 13:6; 34:19). After returning to Kadesh, the scouts brought the fruits of the promised land, spoke of its resources and of its inhabitants. Perhaps this would have been the only mention of Caleb, had it not been for the fact that the information about the inhabitants

$8 \quad$ More on that, see in J. Pudełko, "The (Apparent) Absence of Women in the Praise of the Ancestors (Sir 44-49)," BibAn 6/1 (2016) 107-126.

$9 \quad$ Cf. e.g., R. Petraglio, Il libro che contamina le mani. Ben Sirac rilegge il libro e la storia d'Israele (Theologia 4; Palermo: Agustinus 1993); J. Corley, "Joshua as a Warrior in Hebrew Ben Sira 46: 1-10," Deuterocanonical and Cognate Literature Yearbook 2010. Visions of Peace and Tales of War (eds. J. Liesen - P.C. Beentjes) (Berlin - New York: De Gruyter 2010) 235; A. Demitrów, Quattro oranti nell'Elogio dei Padri (Sir 44-49). Studio dei testi e delle tradizioni (Opolska Biblioteka Teologiczna 124; Opole: Wydawnictwo Wydziału Teologicznego Uniwersytetu Opolskiego 2011); J. Pudełko, Profetyzm w Księdze Syracha (SBL 21; Lublin: Wydawnictwo KUL 2020). 
of Canaan caused fear and then rebellion among the people. Caleb tried to calm the Israelites and prevent them from open rebellion against Moses, as well as to encourage them to conquer the land promised by God (cf. Num 13:30). According to Num 13:30, Caleb's action consisted in silencing the people, persuading them to remain silent (hapax in BH: הסה; cf. use of the particle הס: Judg 3:19; Amos 6:10; 8,3; Hab 2:20; Zeph 1:7; 2:17). ${ }^{10}$ Further, he sought to rekindle the people's faith in God's promises by encouraging them to conquer the land: "we must go up and take possession of it." The terms עלה ("to go up"), ירש ("take possession of") appear here, which reflect God's redemptive action towards Israel (cf. Exod 3:8,17; Lev 20:24). ${ }^{11}$ Interestingly, Num 13:30 only mentions Caleb's statement, saying nothing about Joshua's devoted attitude. ${ }^{12}$ Caleb is thus the first one to show fidelity to God's promise and to give evidence of trust in Him.

Caleb's efforts proved inadequate, as other scouts expressed open reluctance to conquering Canaan (cf. Num 13:31-33). ${ }^{13}$ This led to an open rebellion of the people and grumbling against Moses and Aaron. There appeared willingness to return to Egypt (cf. Num 14:1-4). Seeing this, Moses and Aaron fell on their faces before the people. If this did not take place in the Tent of Meeting, this gesture signified the deep humility of the leaders before the people, also expressing the awareness of the serious consequences of the people's rebellion against God. ${ }^{14}$ The expedition of the scouts could thus have been a complete failure and even a rejection of God's entire redemptive plan for Israel. The key role in this dramatic situation is played by the faithful scouts Joshua and Caleb (cf. Num 14:6). The gesture of tearing their robes was to express their deep anguish in the face of the crisis that had occurred, a sign of grief and mourning for their unfaithfulness to God (cf. Gen 37:29,34; Lev 13:45; Josh 7:6). ${ }^{15}$ When the idea of electing a new leader and returning to Egypt came up among the Israelites, Joshua, Moses' assistant, and Caleb, who had already openly expressed his desire to conquer Canaan, made their opinion publicly known to the people. They drew attention to the qualities of the land, emphasizing the Lord's favour, who Himself wished to give his people "a land flowing with milk and honey" (cf. Num 14:7-8). Thus,

10 Cf. B.A. Levine, Numbers 1-20. A New Translation with Introduction and Commentary (ABYC 4; New Haven, CT - London: Yale University Press 2008) 357.

11 Cf. G.J. Wenham, Numbers. An Introduction and Commentary (TOTC 4; Downers Grove, IL: InterVarsity 1981) 135.

12 Associating Joshua with Moses too closely would, at first glance, be an impediment to the significance of Joshua's opinion. Cf. Milgrom, Numbers, 106. The absence of Joshua in the first Caleb's speech (Num 13:30) is explained by a different tradition than the P tradition present in Num 14:6. Cf. FretzPanitz, "Caleb (Person)," 808.

13 Cf. Wenham, Numbers, 135.

14 Cf. Milgrom, Numbers, 108; Wenham, Numbers, 135.

15 Cf. Milgrom, Numbers, 108; Wenham, Numbers, 136; Levine, Numbers 1-20, 363. 
the main argument of the faithful scouts was God's redemptive will and His actions toward Israel. They did not stop at the fact of emerging difficulties, threats from the inhabitants of Canaan, but wished to undertake trustfully the work ordered to them by the Lord. The people's opposition to God and Moses also turned against Joshua and Caleb, in such a way that they wanted to stone both of them (cf. Num 14:10). In the further part of the story (cf. Nm 14:11-38), there appears a response from God who wanted to punish the rebellion and disobedience of the people. Moses interceded for the people, which ended in the forgiveness of $\sin$. However, the rebellious generation was not supposed to enter the Promised Land again. Caleb was to be an exception. In Num 14:24 God Himself praises Caleb, calling him "my servant" (עבדי), "he has a different spirit" (רוח אחרת עמו), he obeyed - literally "follows me wholeheartedly" (וימלא אחרי). Therefore, he will be brought into the Promised Land, he and his offspring will possess it. Until now, only Moses was called "my servant" by the Lord (Num 12:7; Josh 1:2.7), the time of trial resulted in the appearance of another servant who is faithful to the Lord under all circumstances.$^{16}$ This signifies Caleb's special intimacy with God. The expression "different spirit" denotes an inner disposition, a mental attitude. ${ }^{17}$ Caleb was clearly different from the complaining, doubting, and even rebellious attitude of the Israelites. His attitude was one of obedience and complete loyalty - he "followed me wholeheartedly."

The result of Caleb's fidelity and obedience would be the attainment of the promised inheritance. God promises to lead him into the Promised Land, which he and his offspring will take into possession. Therefore, Caleb is the first heir of the promise, about which God informs Moses (cf. Num 14:24b). This promise, which is also God's solemn oath, is repeated to Moses and Aaron and extended to Joshua as well. Among those who left Egypt, no one experienced the fulfilment of God's promise, except for two faithful scouts, Joshua and Caleb. This is so important that the acknowledgement of God's promise appears several times in the Book of Numbers (cf. Num 14:30,38; 26:65; 32:12), in the Book of Deuteronomy (cf. Deut 1:35), in the Book of Joshua (cf. Josh 21:12) and in the Book of Judges (cf. Judg 1:20).

References to Caleb can also be found in the descriptions of seizing Canaan in the Book of Joshua, where the promise given to him by God is fulfilled in a distinct and consistent manner. When the territory is divided after the conquest of Canaan, Caleb reminds Joshua of God's will communicated to Moses at Kadesh Barnea. After 45 years, despite his old age, a loyal scout confirmed his readiness to take over the land which Lord had promised to him. After receiving Joshua's

16 Cf. R.D. Cole, Numbers (NAC 3B; Nashville, TN: Broadman \& Holman 2000) 233.

17 Cf. Levine, Numbers 1-20, 368; Milgrom, Numbers, 113. 
blessing, Caleb and his offspring became heirs of Hebron (cf. Josh 14:5-14). ${ }^{18}$ This fact is repeated in Josh 15:13-19, adding a mention of the conquest of Debir by Caleb's nephew, Othniel, which made it possible for him to marry Caleb's daughter, Achsah. Not without significance is the fact that the same episode appears at the beginning of the Book of Judges (cf. Judg 1:12-20). It is a model instance of the effects of fidelity and reliance on God, which are the best "weapon" for successive generations of devoted Israelites in the conquest and taking possession of the Promised Land. ${ }^{19}$

Caleb and his offspring are present in the lineage of the Judah tribe (cf. 1 Chr 2:8-55; 4:11-15). The chronicler includes two different Calebs on two registers of Judah's descendants. Caleb, son of Jephunneh, was an essential figure in the story of the Canaan conquest as one of Moses' envoys. In terms of their descent, Caleb and Calebites are associated with southern Canaan (Josh 15:13-17; Judg 1:20; 2 Sam 25:2-3). The chronicler used the priestly source according to which Caleb was to be a Judean (Num 13:6; 34:19). ${ }^{20}$ The latest mention of Caleb is found in 1 Macc 2:65 in Mattathias' pre-death speech. The author of the book recalls the most influential figures in Israel history, who, through their heroism and love of their homeland, are to be an example for the fighting insurgents. ${ }^{21}$ It emphasises the significance of Caleb's testimony during the Israelite rebellion. His consistent fidelity resulted in inheriting the Promised Land. Though all the scouts saw the value and beauty of the earth, Caleb and Joshua were the only ones who dared to directly stand up for radical obedience to God's will. These

18 Cf. Wypych, Ksiega Jozuego, 345.

19 "The episode with Caleb, which is evoked here by the book's editor, has a symbolic dimension. Through the figure of Caleb, Moses' faithful servant, the Deuteronomist connects Judah's activity to Joshua's former victorious and blessed by God campaign, because after the death of his son Nun $(1: 1 ; 2: 8)$, Caleb was one of the few representatives of this generation who know the Lord (cf. 2:6-10), faithfully and obediently fulfilling his will, which had been revealed since Moses' time. At this point, the combination of the fate of Caleb and Judah is another theological measure aimed at the best possible introduction of the family, which in the future will ensure the stability of the monarchy in Israel and Judah. As seen against the background of the most tremendous military success achieved by the Israeli generations after Joshua's death, Caleb's attitude also has a parenetic overtone. Quoting the aged Caleb in the most positive passage of the book, the editor seems to remind us of his extraordinary courage in battle, and above all, of the trust that he and Joshua had for God and Moses. The clearest evidence of his fearless and faithful service was the intelligence operation in Canaan, in which he and Joshua represented Judah's generation (Num 13:6), and the heroism shown when reporting on this expedition, when he was the only one among the people to show his unyielding faith in God's power and grace (Num 13:30; cf. 14:5-10).” D. Dziadosz, Ksiega Sędziów. Rozdział 1-5. Wstęp, przektad z oryginału, komentarz (NKB.ST 7/1; Częstochowa: Edycja Świętego Pawła 2019) 215.

20 Cf. A. Tronina, Pierwsza Księga Kronik. Wstęp, przektad z oryginatu, komentarz (NKB.ST 10/1; Częstochowa: Edycja Świętego Pawła 2015) 149.

21 Cf. J. Nawrot, Pierwsza Księga Machabejska. Rozdziaty 1,1-6,16. Wstęp, przekład z oryginatu, komentarz (NKB.ST 14/1; Częstochowa: Edycja Świętego Pawła 2016) 532. 
were values significant in the context of the struggle for identity during the Maccabean rebellion. ${ }^{22}$

Caleb's portrayal in the Books of the Old Testament is one of coherence and clarity. Even though there is no certainty when it comes to his background and how he belongs to the tribe of Judah, he is considered to be a positive figure through and through. He may be an example of a man who joined the people of Israel and showed great radicalism in his fidelity and obedience. For the recipients of the scriptures, he became a clear example of the accomplishment of God's promises. This was made possible due to full obedience to God even in the reality of an ordeal.

\section{The Context of Caleb's Introduction in The Praise of the Fathers (Sir 44-49)}

With the praise of Joshua ${ }^{23}$ and Caleb (Sir 46:1-10), another stage in the story begins in The Praise of the Fathers (Sir 44-49), which can be identified with another part of the Hebrew Bible, namely the collection of the Prophets. ${ }^{24}$ In this part of The Praise of the Fathers, Burton L. Mack distinguishes the stage of land conquest (cf. Sir 46:1-12) and, in the middle of story, the stage of prophets and kings (cf. Sir 46:13-49:10). ${ }^{25}$ Pancratius C. Beentjes thinks that in 46:1, the second part

22 "However, the most essential element of Caleb's testimony was not the description of the value of the land itself, since it was presented in the same manner by those who, in the end, opposed entering it (Num 13:27). What Caleb did was an attempt to withhold the nascent rebellion, based on the belief that seizing the land was possible for the people if they remained faithful to God's commands (Num 13:30; 14:6-9). Furthermore, he was ready to die rather than to abandon fulfilling God's will (Num 14:10). Such an attitude had to be rewarded with God's decision to let Caleb and his bloodline enter the Promised Land (Num 14:24,30,38; 26:65; 32:12; Deut 1:35-36; Josh 14:7) and then let him take up his share amongst other tribes of Israel (Josh 14:6-15; 15:13-20; 21:12). On the example of Caleb, the author portrays the connection between the land and fidelity to God's commands." Nawrot, Pierwsza Księga Machabejska, 541-542.

23 The praise of Joshua (Sir 46:1-8) was included in the monograph by Judyta J. Pudełko (Profetyzm w Księdze Syracha, 168-200). Cf. Petraglio, Il libro che contamina le mani, 151-179; B.M. Zapff, Jesus Sirach 25-51. Kommentar zum Alten Testament mit der Einheitsübersetzung (NEchtB 39; Würzburg: Echter 2010) 336-340.

24 On this topic, see: L.G. Perdue, "Ben Sira and the Prophets," Intertextual Studies in Ben Sira and Tobit. Essays in Honor of Alexander A. Di Lella, O.F.M. (eds. J. Corley - V. Skemp) (CBQMS 38; Washington, D.C.: Catholic Biblical Association of America 2005) 132-154; P.C. Beentjes, "Prophets and Prophecy in the Book of Ben Sira," Prophets, Prophecy, and Prophetic Texts in Second Temple Judaism (eds. M.H. Floyd - R.D. Haak) (LHBOTS 427; New York - London: Clark 2006) 135-150.

25 Each of these two stages ends with a mention of collective heroes. The first stage includes the Judges (Sir 46:11-12), and the second one mentions the Twelve Prophets (Sir 49:10). B.L. Mack, Wisdom and the Hebrew Epic. Ben Sira's Hymn in Praise of the Fathers (Chicago, IL - London: University 
of praise begins and ends in 50:24 in a reference the present day, similarly as the ending of the first part related to the Torah (cf. Sir 44:16-Sir 45:26). ${ }^{26}$ Adopting the canonical criterion, Alon Goshen-Gottstein distinguishes the "Prophets" stage which follows the "Torah" stage. ${ }^{27}$ Jean Louis Ska describes this stage of history in a similar manner (cf. Sir 46:1-49:10) ${ }^{28}$ Firstly, Joshua (cf. Sir 46:1-8), Caleb (cf. Sir 46:7-10) and the Judges (collectively; cf. Sir 46:11-12) ${ }^{29}$ appear, representing two concepts of the Promised Land conquest (Joshua's quick and the peaceful infiltration of the Judges period). The text of Caleb's praise (Sir 46:7-10) is combined with Joshua's praise (Sir 46:1-8). Thus, the first two verses of the text (Sir 46:7-8) concern the common story of Joshua and Caleb, who performed an act of mercy towards their people, so that Israel would learn God's fidelity, abandon the path of infidelity and grumbling, and place trust in their Lord anew. ${ }^{30}$ The final verses $(9-10)$ focus on Caleb himself, referring to his inheritance of the Promised Land.

of Chicago Press 1985) 39-40; J. Pudełko, "Periodyzacja dziejów Izraela w Pochwale ojców Księgi Syracha (Syr 44-49)," VV 35 (2019) 52.

26 Por. P.C. Beentjes, "The «Praise of the Famous» and Its Prologue. Some Observations on Ben Sira 44:1-15 and the Question on Enoch in 44,16," Bijdr 45 (1984) 380.

27 Cf. A. Goshen-Gottstein, "Ben Sira's Praise of the Fathers: A Canon-Conscious Reading," Ben Sira's God. Proceedings of the International Ben Sira Conference, Durham - Ushaw College 2001 (ed. R. Egger-Wenzel) (BZAW 321; Berlin: De Gruyter 2002) 250.

28 Cf. J.-L. Ska, "The Praise of The Fathers in Sirach (Sir 44-50) and The Canon," J-L. Ska, The Exegesis of the Pentateuch. Exegetical Studies and Basic Questions (FAT 66; Tübingen: Mohr Siebeck 2009) 191.

29 The judges are presented collectively and generally since they were not prophets, unlike the last judge - Samuel. Cf. Goshen-Gottstein, "Ben Sira's Praise of the Fathers," 250.

30 Demitrów (Quattro oranti, 41-42) specifies two essential elements in Joshua and Caleb's pericope (46:1-10): $1-6$ and 7-8, to which he adds a reference to Caleb and his descendants - 9-10. Combining the presentation of Joshua and Caleb (Sir 46:1-10), Jeremy Corley ("Joshua as a Warrior in Hebrew Ben Sira 46:1-10," 243) draws attention to the "refrains," constituting the summary of the two parts of the text. According to $46: 6 \mathrm{~cd}$, the Gentiles are supposed to learn of the power of the God of Israel with which Joshua fights. In 46:10ab the Israelites are supposed to see that it is worth following the Lord. 


\section{The Text of Sir 46:7-10 and Its Translation}

The Greek text is the basis of the analysis ${ }^{31}$ :

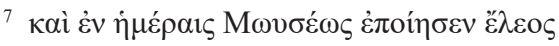

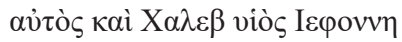

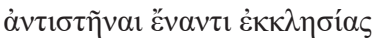

$\kappa \omega \lambda \tilde{v} \sigma \alpha 1 \lambda \alpha o ̀ v \dot{\alpha} \pi$ ò $\alpha \mu \alpha \rho \tau i ́ \alpha$

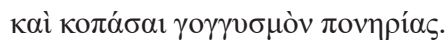

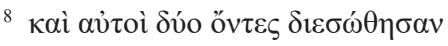

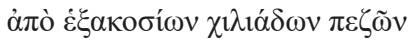

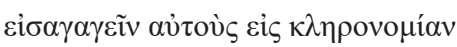

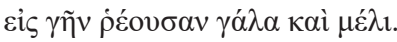

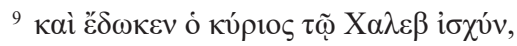

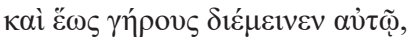

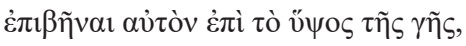

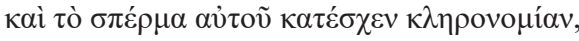

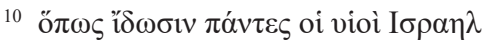

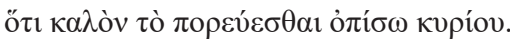

${ }^{7}$ And in the days of Moyses he did mercy,

he and Chaleb son of Iephonne,

to oppose an assembly,

to restrain people from sin

and to still grumbling of wickedness.

${ }^{8}$ And these were the two that escaped out

of the six hundred thousand infantry

to lead them into an inheritance,

into a land flowing with milk and honey.

${ }^{9}$ And the Lord gave Chaleb strength,

and until old age it remained with him

so that he went up to the height of the land

and his seed obtained an inheritance

${ }^{10}$ in order that all the sons of Israel might see

that it is good to walk behind the Lord. ${ }^{32}$

31 Even though the Book of Sirach was written in Hebrew, its Greek version constitutes a fully preserved canonical text. For this reason, in this article, the main, but not the only, research text will be the Greek version of the Book of Sirach. The Greek text and numbering of the verses used in this work come from the Göttingen Septuagint: J. Ziegler (ed.), Sapientia Iesu Filii Sirach, 2 ed. (Septuaginta. Vetus Testamentum Graecum Auctoritate Academiae Scientiarum Gottingensis editum 12/2; Göttingen: Vandenhoeck \& Ruprecht 1980) 342-343.

32 The English translation of the Greek text follows A. Pietersma-B.G. Wright (eds.), The New English Translation of the Septuagint (Oxford: Oxford University Press 2007). 
The Hebrew text will constitute an auxiliary text in the analysis. It comes from $\mathrm{ms}$ B of the Cairo geniza (12th century) and is damaged in a few places. ${ }^{33}$ Proposals for the reconstruction of the damaged fragments were proposed in the translation of the Hebrew text, based on the Greek and Syrian texts.

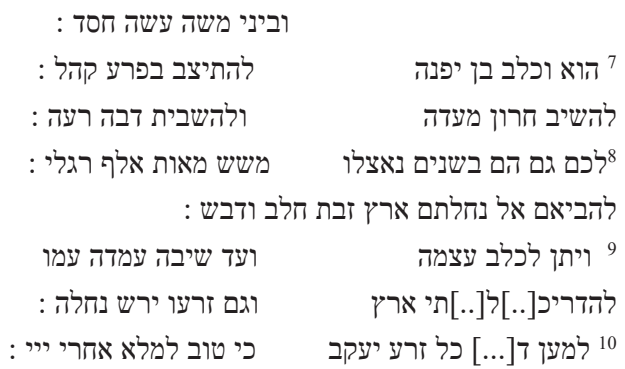

And in the days of Moses he performed mercy. ${ }^{34}$

${ }^{7} \mathrm{He}$ and Caleb son of Iephonne,

By taking a stand at the rebelling of the assembly,

So as to turn away fury from the congregation,

And so as to bring to an end a malicious ill report.

${ }^{8}$ Therefore even both of them were removed

From the six hundred thousand on foot,

So as to bring them in to their inheritance,

A land flowing with milk and honey

${ }^{9}$ And he gave to Caleb vitality,

And until old age it remained with him,

To cause [him to tread] [on the high places] ${ }^{35}$ of the land,

And also his offspring took possession of an inheritance,

${ }^{10}$ So that all the offspring of Jacob might kn[ow], ${ }^{36}$

That it is good to follow fully after YHWH. ${ }^{37}$

33 P.C. Beentjes (ed.), The Book of Ben Sira in Hebrew. A Text Edition of All Extant Hebrew Manuscripts and a Synopsis of All Parallel Hebrew Ben Sira Texts (VTSup 68; Leiden - New York - Köln: Brill 1997) 82; cf. C. Mopsik, La Sagesse de ben Sira. Traduction de l'hébreu, introduction et annotation (Collection «Les Dix Paroles»; Lagrasse: Verdier 2003) 291-292.

34 In the critical edition of the Hebrew text 46,6f (וביני משה עשה חסד) is 7a in the Greek and Syrian texts.

35 Proposal of reconstruction:להדריכ[ עי]ל [במ] תי ארץ. Cf. V. Morla, Los manuscritos hebreos de Ben Sira (Asociación Bíblica Española 59; Estella: Verbo Divino 2012) 305; Demitrów, Quattro oranti, 37.

36 Proposal of reconstruction: למען ד[עת] כל זרע יעקב. Cf. Morla, Los manuscritos hebreos de Ben Sira, ${ }^{305}$; Demitrów, Quattro oranti, 38.

37 The English translation of the Hebrew text follows with minor exceptions Corley, "Joshua as a Warrior in Hebrew Ben Sira 46:1-10," 233. 


\section{Joshua and Caleb - Faithful Witnesses (Sir 46:7-8)}

The praise of Caleb is initially connected with the praise of Joshua. In his presentation of the story, Sirach goes back from the time of Canaan occupation (Sir 46:1-6) to the times of wandering across the desert (Sir 46:7-8). This is

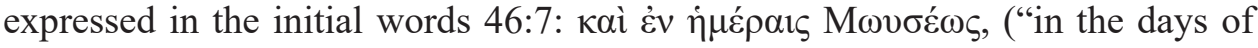
Moyses"). ${ }^{38}$ The sage is referring to Joshua and Caleb, who are subjects of joint operation. Sirach continues the description of Joshua, but the personal pronoun "he" ( $\alpha$ ớć) appears instead of his name, which emphasises the appearance of the figure of Caleb. The sage refers to an important event which is described in both Num 13-14 and is also addressed in Num 32:6-15; Deut 1:19-46; Josh 14:6-14. ${ }^{39}$ Sirach refers to the people's rebellion against the scouts' report. According to Sirach, Joshua with Caleb "did mercy" (46:7a) in this challenging situation. In the text of LXX the term है $\lambda \varepsilon \circ \varsigma$ ("mercy, compassion, grief, sympathy") appears again, which in the Hebrew version (see 46:6f) is expressed by the word ("fidelity, mercy, clemency, favour, kindness, proximity, fellowship, devotion"). ${ }^{40}$ These terms express continuous, close relationships between people, relatives, masters, and servants. It also refers to the bond of covenant with both God and people. The dimension of this relationship is based on mutual trust, fidelity, loyalty, kindness, and even grace, which is most evident in God's relation to people. God showed his love to people, which is most fully expressed in his mercy. God's love is faithful and merciful, that is, it lasts infinitely, and one may expect it even when it is not awaited. God's mercy is based on His forgiveness and accepting people in their sinfulness and infidelity. ${ }^{41}$ Throughout the history of biblical Israel, God revealed His mercy in various ways. The very act of choosing Israel on

38 In the Hebrew text, in 46:6f, the following words are found: וביני משה עשה חסד ('And in the days of Moses he performed mercy").

39 Cf. J.G. Snaith, Ecclesiasticus or The Wisdom of Jesus Son of Sirach (The Cambridge Bible Commentary on The New English Bible; Cambridge: Cambridge University Press 1974) 229; A. Minissale, Siracide (Ecclesiastico). Versione - Introduzione - Note (Roma: Edizioni Paoline 1980) 220; P.W. Skehan - A.A. Di Lella, The Wisdom of Ben Sira (AB 39; New York- London - Toronto: Doubleday 1987) 519; G. Sauer, Jesus Sirach / Ben Sira (ATD. Apokryphen 1; Göttingen: Vandenhoeck \& Ruprecht 2000) 315; Zapff, Jesus Sirach 25-51, 339.

40 "Hesed always designates not just a human attitude, but also the act that emerges from this attitude. It is an act that preserves or promotes life. It is intervention on behalf of someone suffering misfortune or distress. It is demonstration of friendship or piety. It pursues what is good and not what is evil. Thus the most appropriate translation of hesed is «goodness», «grace», or «kindness»." H.J. Zobel, " "סֶׁ," Theological Dictionary of the Old Testament (eds. G.J. Botterweck - H. Ringgren) (Grand Rapids, MI - Cambridge, U.K.: Eerdmans 1986) V, 51. There are cases when $\check{\varepsilon} \lambda \varepsilon \circ \varsigma$ is the translation of the Hebrew word ("grace," e.g., Gen 19:19; Num 11:15; Judg 6:7), or רחמים ("compassion, mercy," e.g., Deut 13:18).

$41 \quad$ Cf. J. Pudełko, "The Use of the Term éleos («mercy») in the Praise of the Fathers (Sir 44-49)," WST 29/1 (2016) 67. 
the part of God and then fidelity, despite the people's infidelity, was a sign of His mercy. Another essential element was the difficult moments in history, collapse, national catastrophes, and especially the Babylonian exile (586-538 BC). Even during those ordeals, God did not turn away from his sinful people. These events gradually prepared Israel to face the truth of the ultimate salvation, which was to be accomplished in eschatology. In Sir 46:7, Joshua and Caleb are portrayed as ideal rulers, which can be related to the king Josiah described by Sirach, who, at a time of threat to the nation's autonomy, stood radically for fidelity to God. In the Hebrew version of the book both Joshua and Caleb (cf. 46:7) and Josiah (cf. 49:3) performed acts of fidelity, loyalty, and mercy (עשה חסד). ${ }^{42}$

The aforementioned biblical texts about Caleb portray him as Moses's servant, obedient to his commands and, most of all, as a faithful servant of YHWH. He emerges as an explorer of the land of Canaan (cf. Num 13-14), and as a reward for fidelity to God, he receives the promise of land (cf. Josh 14:6-15; 15:13; $21: 12$; $1 \mathrm{Chr} 6: 41$ ), he is a courageous warrior (cf. Josh 15:14-19), ancestor of a nomadic lineage (cf.1 Chr 2:18-24,42-50). ${ }^{43}$ However, Sirach, introducing Caleb in 46:7, focuses on the events described in Num 13-14 and related to the people's reaction to the scouts' actions.

Sir 46:7bcd extensively explains what exercising mercy on the part of Joshua and Caleb consisted in. The sage illustrates this situation as follows: $\dot{\alpha} v \tau 1 \sigma \tau \tilde{\eta} v \alpha 1$

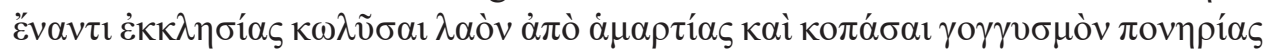
("to oppose an assembly, to restrain people from sin and to still grumbling of wickedness"), להתיצב בפרע קהל להשיב חרון מעדה ולהשבית דבה רעה ("by taking a stand at the rebelling of the assembly, so as to turn away fury from the congregation, and so as to bring to an end a malicious ill report"). Both versions speak of opposing the inappropriate attitude of rebellion. In the LXX, it is expressed by the verb $\dot{\alpha} v \theta i ́ \sigma \tau \eta \mu$ ("to oppose, to withstand"), which appears in confrontation with the enemy (cf., e.g., Lev 26:37; Deut 7:24; 9:2; 23:9; להתיצב בפרע קהל Josh 7:13; Judg 2:14). In the Hebrew text, the expression ("by taking a stand at the rebelling of the assembly") refers to another severe situation of the people's sin. When the golden calf was fashioned in the desert, Moses notices the "wildness" of the people, which, as in Sir 46:7H, is expressed by

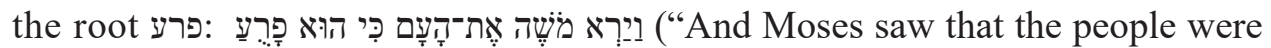
running wild," Exod 32:25). ${ }^{44}$ These are situations in which the people lost both

42 Cf. Corley, "Joshua as a Warrior in Hebrew Ben Sira 46:1-10," 235; Demitrów, Quattro oranti, 90.

43 Cf. Petraglio, Il libro che contamina le mani, 171.

44 Corley ("Joshua as a Warrior in Hebrew Ben Sira 46:1-10," 236) suggests reading בפרע after the Syrian version: בפרץ ("scratch, slot, breach, crack, collapse, adversity"). Therefore, Joshua and Caleb faced a fall, "cracks" - that is, the apostasy of the people, just as in Sir 45:23 Phinehas acted against the unfaithful people. And the root פרע appears in Sir 47:26 when the apostasy of Rehoboam is mentioned. 
their identity and their focus on obedience to God, which, after all, was the guarantee of life. ${ }^{45}$ According to the message of Num 13-14, Joshua and Caleb resisted the people's rebellion, and they were the only ones who opposed the reluctance to conquer the Promised Land. While other scouts argued about the impossibility of conquering the Promised Land, Caleb reassured the people, resisting the rising voices, acknowledging the possibility of conquering Canaan (cf. Num 13:30). ${ }^{46}$ Thus, Joshua and Caleb "kept the people from sin," that is, from the people's turning away from God's will. ${ }^{47}$ Andrzej Demitrów notes that Sir 46:7G avoids the anthropomorphism which is present in the Hebrew version: להשיב חרון מעדה ("turn away fury from the congregation"). The theme of "God's anger" as a reaction to the people's sin is present in the descriptions of the Book of Numbers (cf. Num $25: 4 ; 32: 14$ ) as a passion resulting from His love for the people, a love disillusioned by the unfaithfulness to the covenant, thanks to which the people would attain their fulness of life and identity. ${ }^{48}$ In Sir 46:7d, the sage gives

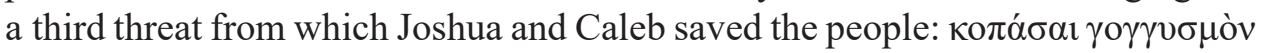

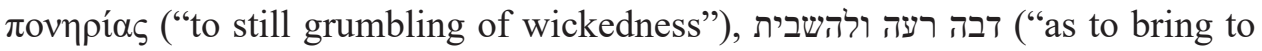
an end a malicious ill report"). In Sir 46:7G, there is a mention of "grumbling,

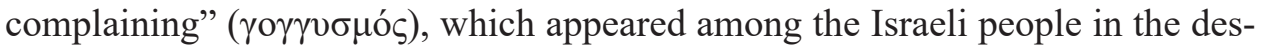
ert and concerned the lack of food (cf. Exod 16:7,8,9,12). The Hebrew version uses the term דבה ("grumbling, ill report, bad news, defamation, slander"), which describes the people's grumbling at the scouts' bad news, the frightening descriptions of the giants inhabiting Canaan. Those who spread bad news were met by an unexpected death (cf. Num 13:33; 14:36). ${ }^{49}$ The people's grumbling may indicate doubting God's promises, even though they were led out of Egypt and experienced numerous blessings in the desert. ${ }^{50}$ Joshua and Caleb - on the contrary - conveyed to the people words of hope that would form a positive image of the land to be conquered (cf. Num 14:7-9). They themselves proved to be men of great courage; they prevented the death penalty for all people grumbling against God's will because of bad news spread by scouts. The act of Joshua and Caleb was, therefore, an act of fidelity, loyalty to God and mercy towards the people. ${ }^{51}$ Fidelity to God was about unshakeable trust in God's promise of receiving the Promised Land and inspiring courage in the people. The act of Joshua and Caleb was, contrary to opposing opinions, a radical declaration for God and His

\footnotetext{
45 Cf. Demitrów, Quattro oranti, 92.

46 Cf. Corley, "Joshua as a Warrior in Hebrew Ben Sira 46:1-10," 235.

47 Cf. Petraglio, Il libro che contamina le mani, 177.

48 Cf. Demitrów, Quattro oranti, 94.

49 Cf. Petraglio, Il libro che contamina le mani, 177-178.

50 Cf. H. Langkammer, Księga Syracha. Wstęp, przekład z oryginatu, komentarz, ekskursy (PŚST 8/5; Poznań: Pallottinum 2020) 388.

51 Cf. Skehan - Di Lella, The Wisdom of Ben Sira, 519.
} 
will, which was also expressed in the gesture of tearing their robes in the face of the rebellion and complaints of the people (cf. Num 14:6). ${ }^{52}$ As a result, Joshua and Caleb received inheritance in the Promised Land, which the following verses treat about (cf. Sir 46:8-10).

In Sir 46:8, the sage clearly shows a strong contrast between the entire people (cf. Sir 16:10), and two faithful scouts: Joshua and Caleb..$^{53}$ Their fidelity is met with a generous response from God. ${ }^{54}$ Both the Greek and the Hebrew versions, when speaking of their salvation, use the passive voice (őv $\tau \varepsilon \zeta \delta \varepsilon \varepsilon \sigma \dot{\theta} \theta \eta \sigma \alpha v$; נאצלו to emphasise God's involvement in the heroes' lives. It is God who saves human life from danger (cf. Num 14:38; 32:12; Deut 1:36,38). ${ }^{55}$ The figures of Joshua and Caleb are contrasted with the people of Israel, who were led out of Egypt. Based on Exod 12:37 and Num 11:21, the sage gives their number: "six hundred thousand walkers." George E. Mendenhall notes that the Hebrew term אלף need not necessarily mean "a thousand" but may refer to a "clan, troop, unit" (cf. Num 31:4-6). ${ }^{56}$ Initially, the term אלף was an unidentified number, indicating a vast, countless crowd, which would emphasise the tradition of the multitude of Israel. ${ }^{57}$ The presence of the term ("legs, footmen, walkers") may additionally have military connotations, indicating warriors in the unit (cf. Judg 20:2; 1 Sam 4:10; 15:4; 2 Sam 8:4; 10:6; 1 Kgs 20:9; 2 Kgs 13:7; $1 \mathrm{Chr} 18: 4) .{ }^{58}$ The sexagesimal system functioning in Mesopotamia was multiplied in this case in order to indicate a huge crowd. ${ }^{59}$ Six hundred thousand can also mean that all of the people or represent an idealistic metaphor for "all the sons of Israel" (כל בני ישראל), taking into the account the fact that the numeric value of the Hebrew letters is equal to $653 .{ }^{60}$

52 Cf. Zapff, Jesus Sirach 25-51, 338-339. Corley ("Joshua as a Warrior in Hebrew Ben Sira 46:1-10," 237) remarks that particularly the Hebrew version of Sir 46:7 reflects, also on the literary level, the description of Num 13-14.

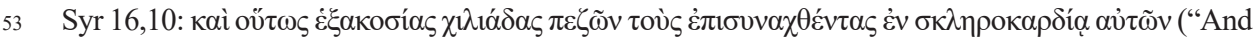
so six hundred thousand walkers gathered in the hardness of their heart").

54 Cf. Petraglio, Il libro che contamina le mani, 179; Skehan - Di Lella, The Wisdom of Ben Sira, 519.

55 Cf. Demitrów, Quattro oranti, 101.

56 Cf. G.E. Mendenhall, “The Census Lists of Numbers 1 and 26,” JBL 77 (1958) 66.

57 Cf. S.E. Loewenstamm, The Evolution of the Exodus Tradition (Perry Foundation for Biblical Research in the Hebrew University of Jerusalem; Jerusalem: Hebrew University of Jerusalem - Magnes Press 1992) 227.

58 Cf. Demitrów, Quattro oranti, 100-101.

59 Cf. U.M.D. Cassuto, A Commentary on the Book of Exodus (Jerusalem: Hebrew University of Jerusalem - Magnes Press 1967) 147.

60 Cf. J. de Vaulx, Les Nombres (SB; Paris: Gabalda 1972) 67. The fact that according to Exod 38:26; Num 3:39, the population of Israel was 625 550; according to Num 1:45, 603 550; according to Num 26:51, 601 730, and according to Exod 12:37, Num 11:21, 600000 denotes an approximate, schematic or symbolic value of this number. W.H.C. Propp, Exodus 1- 8. A New Translation With Introduction and Commentary (New Haven, CT - London, U.K.: Yale University Press 2008) 414. Por. Sauer, Jesus Sirach, 316. 
Joshua and Caleb's fidelity is met with God's response - they obtain the Promised Land. Sir 46:8b draws attention to the role of heroes towards the people. They

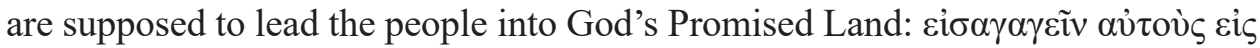

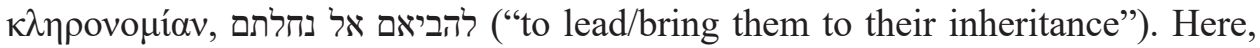
the author highlights the reality of the inheritance gift which comes from and is bestowed by God. In Num 14:24, the promise of land inheritance refers only

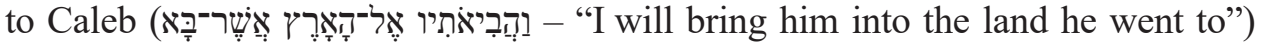
and his descendants, Joshua is added only in 14:30, but "their inheritance," i.e., the land of the people, is not mentioned. Although it can be noted that the inheritance promise given to Caleb and Joshua appears separately, nevertheless

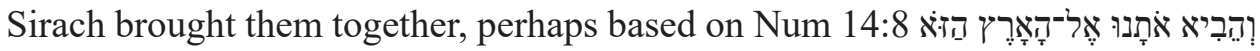
("And he will lead us into that land"). ${ }^{61}$ Already in Sir 46:1, one of Joshua's significant tasks appeared, which was to cause "Israel to take over their inheritance." This refers not so much to those who left Egypt and disobeyed God but to new generations, who were born in the desert. ${ }^{62}$

Sir 46:8cd speaks of the introduction "into a land flowing with milk and

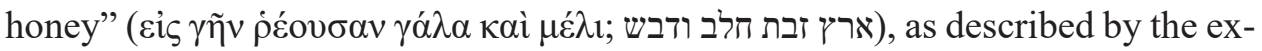
plorers (cf. Num 13:27). The text in Num 13 also recounts the wonderful and abundant fruits of the witnessed land: grapes, pomegranates and figs (cf. 13:23). Showing them to the people, they described the Promised Land as a land "flowing with milk and honey" (Num 13:27). ${ }^{63}$ Caleb, in response to the mutter of the people who wanted to return to Egypt, explained to them that the land which Lord wanted to bestow upon them was good, "flowing with milk and honey" (cf. Num 14:8). ${ }^{64}$ "Milk and honey" are foods that represent the reality of abundance, satiating hunger and appetite. ${ }^{65}$ It is a kind of food specific to pastoral peoples, because the abundance of milk indicates numerous cattle herds, and honey symbolizes the availability of food prepared by bees and its sweet taste. ${ }^{66}$ Milk was also perceived as a symbol of purity (cf. Gen 49:12; Deut 5:12) as well as abundance and wealth, often associated with fat (cf. Isa 60:15-16; Joel 4:18). Honey may mean not only the product of bees, but also the sweet juice of the nu-

\footnotetext{
61 Cf. Demitrów, Quattro oranti, 103-104.

62 Cf. Corley, "Joshua as a Warrior in Hebrew Ben Sira 46:1-10," 238.

63 Cf. Minissale, Siracide, 220; Skehan - Di Lella, The Wisdom of Ben Sira, 519; Sauer, Jesus Sirach, 315; Petraglio, Il libro che contamina le mani, 179.

64 Cf. Corley, "Joshua as a Warrior in Hebrew Ben Sira 46:1-10," 239. The land "flowing with milk and honey" is an expression found in various books of the Bible as a synonym for God's gift to Israel: Exod 3,8.17; 13,5; 33,3; Lev 20,24; Deut 6,3; 11,9; Josh 5,6; Jer 11,5; 32,22; Ezek 20,6. Skehan - Di Lella, The Wisdom of Ben Sira, 519.

65 Cf. Zapff, Jesus Sirach 25-51, 339.

66 Cf. Cassuto, A Commentary on the Book of Exodus, 34.
} 
merous kinds of fruit ripening in the land of Canaan. ${ }^{67}$ God's gift was meant to be a reflection of His generosity. So, in the sage's view, Joshua and Caleb received from God what they were deeply convinced of, believing in the words of God's promise.

\section{Caleb - Fidelity Rewarded (Sir 46:9-10)}

In the following verses, Sirach refers only to the figure of Caleb and his offspring, emphasizing the value of his person independently of Joshua. Sir 46:9 refers to fulfilling the promise of God, but only to Caleb and his offspring: $\kappa \alpha i$

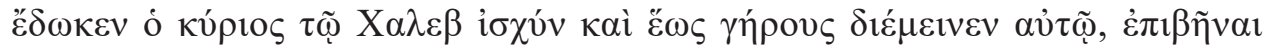

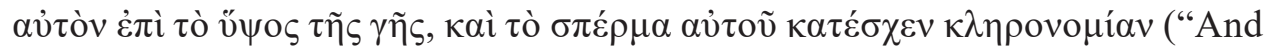
the Lord gave Chaleb strength, and until old age it remained with him so that he went up to the height of the land and his seed obtained an inheritance"), "And he ויתן לכלב עצמה ועד שיבה עמדה עמו להדריכ[..]ל[..]תי ארץ וגם זרעו ירש נחלה gave to Caleb vitality, and until old age it remained with him, to cause [him to tread] [on the high places] of the land"). The first attribute of the person of Caleb

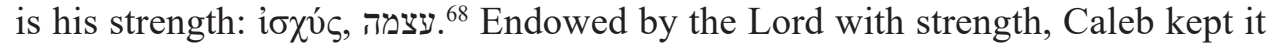
until old age, having strength at the age of eighty-five (cf. Josh 14:10-12).$^{69}$ This strength even enabled him to participate in war expeditions as in his earlier years: "I am still as strong today as the day Moses sent me out. I'm just as vigorous to go out to battle now as I was then" (Josh 14:11). Although Sirach does

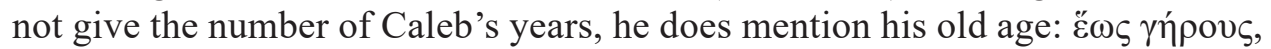
ועד שיבה , which means old age. ${ }^{70}$ Here, the sage wants to highlight the effects of fidelity to God. A person who obeys God can enjoy His blessings, which is also expressed by possessing health and a strong body. ${ }^{71}$ According to Sirach, Caleb's powers were manifested, among other things, in his ability to move: غं $\pi \beta \tilde{\eta} v \alpha r$

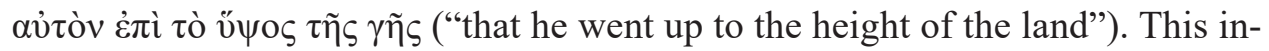
formation is taken from the account of Josh 14:9 and Deut 1:36, which mentions the possession of the land that Caleb ascended, suggesting a military conquest. ${ }^{72}$

67 Cf. V.P. Hamilton, Exodus. An Exegetical Commentary (Grand Rapids, MI: Baker Academic 2011) 56.

68 The Greek term i $6 \chi 0$ ' $\varsigma$ "strength" translates to the rare Hebrew term עצמה "force, might" which refers to both divine (Isa 40:29) and human (Nah 3:9) stamina. Cf. Demitrów, Quattro oranti, 107; Corley, "Joshua as a Warrior in Hebrew Ben Sira 46:1-10," 239.

69 Cf. V. Hamp, Sirach (EB 13; Würzburg: Echter 1952) 127; Snaith, Ecclesiasticus, 230; Skehan - Di Lella, The Wisdom of Ben Sira, 519; Sauer, Jesus Sirach, 316.

70 Cf. Demitrów, Quattro oranti, 108.

71 Cf. Corley, "Joshua as a Warrior in Hebrew Ben Sira 46:1-10," 239.

72 Cf. Petraglio, Il libro che contamina le mani, 179; Demitrów, Quattro oranti, 108. 
In the same speech of his, Caleb asked Joshua to give him the promised mountain as an inheritance: "Now give me this hill country that the Lord promised me that day" (Josh 14:12). Considering Josh 15:13, one may note here a reference to receiving Hebron, or Kiriath Arba, the main city of the Anakites. ${ }^{73}$ Caleb's

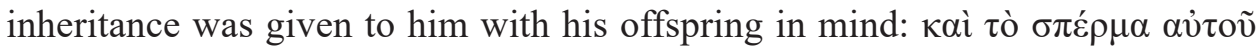

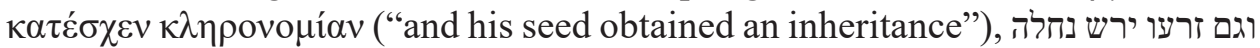
("And also his offspring took possession of an inheritance," Sir 46:9d). God's promises to Caleb who had shown his fidelity were extended to his descendants who would inherit his land: "and his descendants will inherit it" (Num 14:24; cf. Deut 1:36; Josh 14:13-14). ${ }^{74}$ Referring to these accounts, Sirach highlights God's bestowal of gifts, which Caleb and his descendants came to share. It was not Caleb himself who conquered the lands for himself, but he received them from the Lord. This way, the sage draws attention to God's faithfulness and the irrevocability of His gifts. ${ }^{75}$

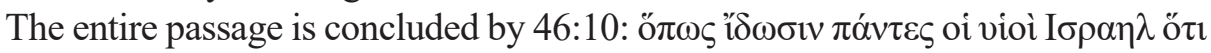

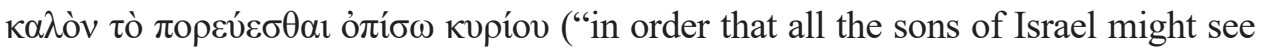
that it is good to walk behind the Lord"), למען ד[...] כל זרע יעקב כי טוב למלא אחר י" ("so that all the offspring of Jacob might kn[ow], that it is good to follow fully after YHWH"). The immediate context suggests that these words refer to Caleb. His fidelity is rewarded by the Lord. The expression "follow the Lord" when referring to Caleb appears in Num 14:24; 32:12 and in Josh 14:8-14. The choice made by Caleb turns out to be the good which affects his earthly life. His obedience to God enabled him to enjoy good health until his old age. ${ }^{76}$ In $46: 6$ e a simi-

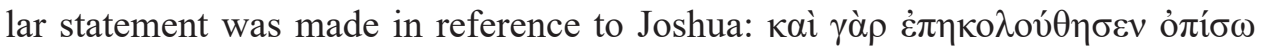

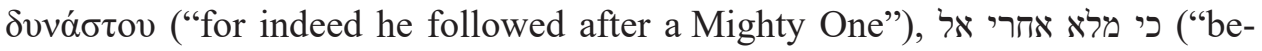
cause he followed God fully"). In this way, Sirach motivates both the military victory achieved through Joshua's mediation (46:6) and the prosperity of a long life in his own land in reference to Caleb (46:10). The motivation behind the presentation of the example of Joshua and Caleb is to shape the proper attitude of the children of Israel/Jacob, who by learning about these examples were invited to follow them. Sirach gave examples of the fidelity of outstanding individuals (Henoch, Noah, Pinchas, Joshua, Caleb) who were able to stand up to the sinful attitudes of the general population. He thus extended an invitation to his fellow countrymen to preserve their identity as "descendants of Jacob/Israel" in the face

73 Cf. Hamp, Sirach, 127; Snaith, Ecclesiasticus, 230; Minissale, Siracide, 221; Skehan - Di Lella, The Wisdom of Ben Sira, 519; Sauer, Jesus Sirach, 316; Petraglio, Il libro che contamina le mani, 180.

74 Cf. Skehan - Di Lella, The Wisdom of Ben Sira, 519; Corley, "Joshua as a Warrior in Hebrew Ben Sira 46:1-10," 240.

75 Cf. Demitrów, Quattro oranti, 110.

76 Cf. Skehan - Di Lella, The Wisdom of Ben Sira, 519; Corley, "Joshua as a Warrior in Hebrew Ben Sira 46:1-10," 241. 
of all pagan incursions opposing the faith of their fathers. Among them, Caleb, a foreigner who became one of the sons of Israel, also deserved praise for his heroic fidelity to YHWH in a moment of the crisis of the entire people. ${ }^{77}$

The description of Caleb thus becomes, in a way, a complement to the description and example of Joshua, and both point out to posterity how one should fully "follow God" (cf. Sir 46:7.10), that is, show obedience to Him. Burkard M. Zapff compares Joshua and Caleb's opposition to the sin of the people to the attitude of the prophet Nathan (cf. Sir 47:1), who contributed to the conversion of King David. ${ }^{78}$ At the same time, Joshua and Caleb show the people the right model of life, fidelity, and trust in God, even in the situations of ordeal.

\section{Summary}

Sirach presented the figure of Caleb in two parts. Based on the story of the scouts and the people's rebellion (Num 13-14), the sage showed the act of mercy on the part of Joshua and Caleb directed toward their people so that the people would learn of God's faithfulness, abandon the way of unbelief and grumbling, and place trust in their God anew (Sir 46:7-8). Caleb here became a sign of God's merciful action to the benefit of Israel. The presence of the two faithful witnesses was to become convincing both to Israel in the wilderness and to the recipients of Sirach's teachings. The crisis within the community, the rebellion against God, seems far more serious than the struggle with the inhabitants of Canaan. For the rebels may have undone the entire work of the exodus by urging the people to return to Egypt. Therefore, in the following verses of praise (46:7-8), the sage joins Joshua and Caleb in revealing the power of the testimony and persuasion of the two witnesses. Caleb is persuasive not only in his strength, but in his ability to interact with Joshua, his ability to mediate, his encouragement to fulfil God's will, and his own example. Joshua's mission addressed both the people of Israel and the Gentiles, who were able to experience YHWH's action in Israel's favour (Sir 46:1-8). In Sirach's account, Caleb's mission addressed the people of Israel (Sir 46:7-8). Being faithful and obedient, he called his countrymen to adopt this attitude. The resolute obedience of both heroes was to make the people learn of God's faithfulness, give up the way of unbelief and grumbling, and place trust in their Lord anew. The courageous opposition to the rebellion of the whole people was a sign of courage and at the same time a profession of faith in God's promises and setting the direction for the people. Sirach ignores the fact that 
Caleb was a Kenizzite but presents him as an example of a an Israelite faithful to God. The real threat for Caleb was not so much an external enemy but the act of turning away from God - sin. This is a clear signal of Sirach's admonishment to his contemporary Jews, departing from God's Law, seeking fulfilment beyond their identity stemming from the covenant. The sage also shows the effects of fidelity - salvation and fulfilling the promise of the Promised Land gift, which is a symbol of all human aspirations and desires. ${ }^{79}$ The endowment is therefore clearly dependent on the faith of the person being the recipient, inasmuch as they believe in the fulfilment of God's promises.

In the second part of his presentation, specifically referring to taking possession of the Promised Land, Sirach used the text of Josh 14:6-14. The sage presented the consequences of fidelity to God, realized in the life of Caleb himself and his descendants (Sir 46:9-10). Although Sirach did not mention the city of Hebron, an important place in the history of Israel, Abraham's first property in Canaan, he referred to this fact indirectly when he spoke of Caleb's ascent to the highland of the earth. This meant taking possession of these lands. Caleb's old age, the fact of passing, did not change anything in God's plan. Caleb's loyalty to God was the guarantor of his strength, and at the same time it also influenced his descendants, who could continue and develop the promise made to their father. Caleb's work was continued in the figure of his nephew Othniel, one of the future judges of Israel (cf. Judg 3:9). It should be borne in mind that the inheritance of the Calebites is the territory of Judah and Hebron, where David would reign in the future. In this way, the sage of Jerusalem, wanted to educate his listeners about the value of their ancestors' deeds, their fidelity, which reached far into the future. The praise of Caleb ends with emphasising the value of obedience to God. Everyone should become convinced that it is worth "following the Lord."

Sirach saw in his times the need for the presence of true God's intercessors updating the history of salvation, just as Caleb had fulfilled the promises made to Moses in the past. ${ }^{80}$ The sage wanted to instruct his listeners that even amidst great adversities, in the feeling of helplessness, God's power can be revealed through a faithful witness who trusts Him. Caleb's courage and fidelity were in fact an instruction and an encouragement to fight for fidelity to the Law of the Lord. Through his distinctive, consistent attitude, Caleb became an example of a faithful Israelite who lives in obedience to the word of the Lord and encourages others to follow this path. For this reason, Caleb's fidelity gains a timeless value.

Translated by Grzegorz Knyś

79 Cf. Langkammer, Księga Syracha, 389.

80 Cf. Petraglio, Il libro che contamina le mani, 160. 


\section{Bibliography}

Beentjes, P.C., "The «Praise of the Famous» and Its Prologue. Some Observations on Ben Sira 44:1-15 and the Question on Enoch in 44:16," Bijdragen. Tijdschrift voor filosofie en theologie 45 (1984) 374-383.

Beentjes, P.C. (ed.), The Book of Ben Sira in Hebrew. A Text Edition of All Extant Hebrew Manuscripts and a Synopsis of All Parallel Hebrew Ben Sira Texts (Supplements to Vetus Testamentum 68; Leiden - New York - Köln: Brill 1997).

Beentjes, P.C., "Prophets and Prophecy in the Book of Ben Sira," Prophets, Prophecy, and Prophetic Texts in Second Temple Judaism (eds. M.H. Floyd - R.D. Haak) (The Library of Hebrew Bible/ Old Testament Studies 427; New York - London: Clark 2006) 135-150.

Beltz, W., Die Kaleb-Traditionen im Alten Testament (Beiträge zur Wissenschaft vom Neuen Testament 18; Stuttgart: Kohlhammer 1974).

Botterweck, G.J., "כלב," Theological Dictionary of the Old Testament (eds. G.J. Botterweck H. Ringgren) (Grand Rapids, MI - Cambridge, U.K.: Eerdmans 1995) V, 146-157.

Cassuto, U.M.D., A Commentary on the Book of Exodus (Jerusalem: The Hebrew University of Jerusalem - Magnes Press 1967).

Cole, R.D., Numbers (New American Commentary 3B; Nashville, TN: Broadman \& Holman 2000).

Corley, J., "Joshua as a Warrior in Hebrew Ben Sira 46:1-10," Deuterocanonical and Cognate Literature Yearbook 2010. Visions of Peace and Tales of War (eds. J. Liesen - P.C. Beentjes) (Berlin New York: De Gruyter 2010) 207-248.

Demitrów, A., Quattro oranti nell'Elogio dei Padri (Sir 44-49). Studio dei testi e delle tradizioni (Opolska Biblioteka Teologiczna 124; Opole: Wydawnictwo Wydziału Teologicznego Uniwersytetu Opolskiego 2011).

Domański, A., "The Figure of Caleb in Selected Jewish Legends and in the Teaching of the Church Fathers," Studia Loviciensia 7 (2005) 95-107.

Dziadosz, D., Księga Sędziów. Rodziały 1-5. Wstęp, przekład z oryginału, komentarz (Nowy Komentarz Biblijny. Stary Testament 7/1; Częstochowa: Edycja Świętego Pawła 2019).

Fretz, M.J. - Panitz, R.I., “Caleb (Person),” The Anchor Yale Bible Dictionary (ed. D.N. Freedman) (New York: Doubleday 1992) I, 808-810.

Goshen-Gottstein, A., "Ben Sira's Praise of the Fathers: A Canon-Conscious Reading," Ben Sira's God. Proceedings of the International Ben Sira Conference, Durham - Ushaw College 2001 (ed. R. Egger-Wenzel) (Beihefte zur Zeitschrift für die alttestamentliche Wissenschaft Beihefte zur Zeitschrift für die alttestamentliche Wissenschaft 321; Berlin: De Gruyter 2002) 235-267.

Hamilton, V.P., Exodus. An Exegetical Commentary (Grand Rapids, MI: Baker Academic 2011).

Hamp, V., Sirach (Die Heilige Schrift in deutscher Übersetzung, Echter Bibel 13; Würzburg: Echter 1952).

Langkammer, H., Księga Syracha. Wstęp, przektad z oryginału, komentarz, ekskursy (Pismo Święte Starego Testamentu 8/5; Poznań: Pallottinum 2020).

Lemański, J., "Negatywny obraz psa w Biblii: przyczyny i konsekwencje," Colloquia Theologica Ottoniana 1 (2011) 51-96.

Levenson, J.D. - Halpern, B., "The Political Import of David's Marriages," Journal of Biblical Literature 99 (1980) 507-518. 
Levine, B.A., Numbers 1-20. A New Translation with Introduction and Commentary (The Anchor Yale Bible Commentaries 4; New Haven, CT - London: Yale University Press 2008).

Loewenstamm, S.E., The Evolution of the Exodus Tradition (Perry Foundation for Biblical Research in the Hebrew University of Jerusalem; Jerusalem: The Hebrew University of Jerusalem Magnes Press 1992).

Mack, B.L., Wisdom and the Hebrew Epic. Ben Sira's Hymn in Praise of the Fathers (Chicago, ILLondon: University of Chicago Press 1985).

Mendenhall, G.E., "The Census Lists of Numbers 1 and 26," Journal of Biblical Literature 77 (1958) $52-66$.

Milgrom, J., Numbers. The Traditional Hebrew Text with the New JPS Translation (Philadelphia, PA - New York: Jewish Publication Society 1990).

Minissale, A., Siracide (Ecclesiastico). Versione - Introduzione - Note (Roma: Edizioni Paoline 1980).

Mopsik, C., La Sagesse de ben Sira. Traduction de l'hébreu, introduction et annotation (Collection «Les Dix Paroles»; Lagrasse: Verdier 2003).

Morla, V., Los manuscritos hebreos de Ben Sira (Asociación Bíblica Española 59; Estella: Verbo Divino 2012).

Nawrot, J., Pierwsza Księga Machabejska. Rozdziały 1,1-6,16. Wstęp, przekład z oryginatu, komentarz (Nowy Komentarz Biblijny. Stary Testament 14/1; Częstochowa: Edycja Świętego Pawła 2016).

Perdue, L.G., "Ben Sira and the Prophets," Intertextual Studies in Ben Sira and Tobit. Essays in Honor of Alexander A. Di Lella, O.F.M. (eds. J. Corley - V. Skemp) (Catholic Biblical Quarterly Monograph Series 38; Washington, D.C.: Catholic Biblical Association of America 2005) 132-154.

Petraglio, R., Il libro che contamina le mani. Ben Sirac rilegge il libro e la storia d'Israele (Teologia 4; Palermo: Agustinus 1993).

Pietersma, A. - Wright, B.G. (eds.), A New English Translation of the Septuagint (Oxford: Oxford University Press 2007).

Popowski, R., Septuaginta (Prymasowska Seria Biblijna; Warszawa: Vocatio 2013).

Propp, W.H.C., Exodus 1-18. A New Translation With Introduction and Commentary (New Haven, CT - London, U.K.: Yale University Press 2008).

Pudełko, J., "Użycie terminu éleos («miłosierdzie») w Pochwale ojców (Syr 44-49) The Use of the Term éleos («mercy») in the Praise of the Fathers (Sir 44-49)," Warszawskie Studia Teologiczne 29/1 (2016) 66-81.

Pudełko, J., "The (Apparent) Absence of Women in the Praise of the Ancestors (Sir 44-49)," The Biblical Annals 6/1 (2016) 107-126.

Pudełko, J., "Periodyzacja dziejów Izraela w Pochwale ojców Księgi Syracha (Syr 44-49)," Verbum Vitae 35 (2019) 39-76.

Pudełko, J., Profetyzm w Księdze Syracha (Studia Biblica Lublinensia 21; Lublin: Wydawnictwo KUL 2020).

Sauer, G., Jesus Sirach / Ben Sira (Alte Testament Deutsch. Apokryphen 1; Göttingen: Vandenhoeck \& Ruprecht 2000). 
Ska, J.-L., "The Praise of The Fathers in Sirach (Sir 44-50) and The Canon,” J.-L. Ska, The Exegesis of the Pentateuch. Exegetical Studies and Basic Questions (Forschungen zum Alten Testament 66; Tübingen: Mohr Siebeck 2009) 184-195.

Skehan, P.W. - Di Lella, A.A., The Wisdom of Ben Sira (The Anchor Bible 39; New York - London Toronto: Doubleday 1987).

Snaith, J.G., Ecclesiasticus or The Wisdom of Jesus Son of Sirach (The Cambridge Bible Commentary on The New English Bible; Cambridge: Cambridge University Press 1974).

Thomas, D.W., "Kelebh «dog»: Its Origin and Some Usages of It in the Old Testament," Vetus Testamentum 10/4 (1960) 410-427.

Tronina, A., Pierwsza Księga Kronik. Wstęp, przekład z oryginału, komentarz (Nowy Komentarz Biblijny. Stary Testament 10/1; Częstochowa: Edycja Świętego Pawła 2015).

Vaulx, J. de, Les Nombres (Sources Bibliques; Paris: Gabalda 1972).

Wenham, G.J., Numbers. An Introduction and Commentary (Tyndale Old Testament Commentaries 4; Downers Grove, IL: InterVarsity 1981).

Wypych, S., Księga Jozuego. Wstęp, przekład z oryginału, komentarz (Nowy Komentarz Biblijny. Stary Testament 6; Edycja Świętego Pawła: Częstochowa 2015).

Zapff, B.M., Jesus Sirach 25-51. Kommentar zum Alten Testament mit der Einheitsübersetzung (Die Neue Echter Bibel 39; Würzburg: Echter 2010).

Ziegler, J. (ed.), Sapientia Iesu Filii Sirach, 2 ed. (Septuaginta. Vetus Testamentum Graecum Auctoritate Academiae Scientiarum Gotteingensis editum 12/2; Göttingen: Vandenhoeck \& Ruprecht 1980).

Zobel, H.J., "חָסָד," Theological Dictionary of the Old Testament (eds. G.J. Botterweck - H. Ringgren) (Grand Rapids, MI - Cambridge, U.K.: Eerdmans 1986) V, 51. 